\title{
REMEMBERING LESTER... WHAT COMES TO MY MIND?
}

\author{
RECORDANDO A LESTER...,¿¿QUÉ VIENE A MI MENTE?
}

\section{Christel Seebohm}

Bad Godesberg, Bonn

cseebohm@t-online.de

I can hardly bear the thought that my husband's best and most trustworthy friend also had to passs away only two years after Thomas had to die. Remembering Lester, ,... what comes to my mind?

Lester taught me what it means to have a friend, a true friend. Upon Thomas's arrival in the USA to teach at Penn State in the early seventies it was Lester who introduced him to his collegues at the New School for Social Research and at the Society for Phenomenology and Existential Philosophy (SPEP), at the Husserl Circle and also at The Center of Advanced Research in Phenomenology (CARP). He opened him the chance to connect with people who like him had a special interest in phenomenology. Meeting at conferences and equally passionate about advancing phenomenology Lester and Thomas soon became friends, and soon they got together for their private conferences at our home. This became quite a tradition after in 1984 Thomas had accepted a chair at the University of Mainz and we had moved back to Germany. From then on year after year, whenever his itinary allowed, Lester made it a habit to drop by to "check how his friends in Germany were doin". And it always was a pleasure for me to make himself feel at home with us sharing our lives with him. And he became our favourite guest: Tall as he was, he spread out with his things comfortably in our very tiny guestroom and then moved to his special chair to sit reading and working quietly in our gardenroom with its pleasant view, until Thomas came 
down from working in Mainz or down from his study upstairs to join us for our meals, or to celebrate our precious "L'Heure Bleue" with us at teatime when the sun was setting in the afternoon or later at night getting involved in very engaging conversations over a glas of wine. There was an impressive variety of interesting topics for discussion that were of concern to the three of us and Lester was the expert on all of them: New impressions gathered on his latest travels, shared concern about what was happening on the political stage on both sides of the Atlantic, caring about the problems of our environment, for instance in respect to the management of waste and the possibility of the development of the electric car to replace the fuel burning cars with their life threatening effects (Lester was the first one we saw having an electric car parked in front of his house).

All in all we cherished a wide range of interests that came up when we sat together talking. His warm, witty and quite unusual sense of humor set a good note to it. He was a very good listener interested in his fellow human beings, and in his openess of mind and with his keen judgement he never seemed to push his opinion. So sitting together with him always offered food for thought and was a valuable gift in our conversations.

For Thomas, Lester as his friend was essential for his work. During his stays discussing philosophy and especially phenomenology was at the center of their shared interest. Both, it seemed to me, were aiming at the same goal, i.e. Advancing Phenomenology. And in this they deeply respected and admired each other. But the way they dealt with it was quite different: Thomas, due to experiences in his childhood (his father having been a politician) and due to his continuous health problems since he was a child, was not exactly outgoing. Especially in his later years and being retired from his duties at the university, he chose to live and work rather like a hermit. He preferred to live according to the Epicurean motto he had chosen for himself: Lathe biosas, live in seclusion to find inner peace for thinking and working. And he felt he was in good company of quite a few other philosophers before him, as for instance depicted in Albrecht Duerer's etching of St. Hieronymus in his study Lester, being physically strong and not all withdrawn in his mental setup, seemed to me to have a completely different approach to life and to act under his chosen motto: "don't you forget: I am a marine!". 
Equally prolific in his work and thinking as a philosopher Lester also was a perfect networker reaching out to foster and promote phenomenological thinking all over many different countries and cultures travelling tiredlessly to realize new phenomenological projects and organizations all over the world, networking to connect people in different academic settings.

At the base of this was his sharp recognition of academic potential and excelence and a personal generosity of mind and heart that is so rare in human beings in general and also in academic circles. He understood and supported Thomas's work and especially during the last phase of his life, when Thomas had become too weak to get to the university library himself to search for material still relevant, Lester kept sending him copies of books and articles that might still be of mutual interest to his friend. On the other hand he time he generously kept me informed about what was going on the English/American literary seen as well. Thomas died August 2014, right after finishing the last part of the book he had been working on for so many years. "History as a Science and The System of the Sciences" was then published posthumously in 2015. And Lester again gave proof of his dedication and deep friendship for Thomas. He took care that the book's index was complete and saw it through the complex process of publication, which I could never have done for him.

Remembereing Lester: I feel happy and grateful life offered us the chance to have met him and to experience the intellectual depth and the warmth and generosity of his friendship. The times we had together were the good times. He was a friend, a true friend to both of us and he always will be... 